\title{
First report of groundnut ringspot virus in Physalis angulata L.
}

\section{Alessandra de Jesus Boari ${ }^{1}$ - Caterynne de Melo Kauffmann ${ }^{2}$. Ayane Fernanda Ferreira Quadros ${ }^{3}$}

Received: 11 February 2019 / Accepted: 15 April 2019/Published online: 30Apr il 2019

(C) Società Italiana di Patologia Vegetale (S.I.Pa.V.) 2019

Keywords Camapu · GRSV · Pará

Physalis angulata L. (family Solanaceae), known as camapu or juá-de-capote in Brazil, is a medicinal plant with edible fruits native to the Americas. In August of 2017, many camapu plants presented symptoms characteristic of orthotospoviruses, such as branch and leaf necrosis, leaf deformation and necrotic rings, at a tomato plantation located in Altamira (S3 $\left.{ }^{\circ} 16^{\prime} 094^{\prime \prime}, \mathrm{W} 52^{\circ} 23^{\prime} 38.4^{\prime \prime}\right)$, in the state of Pará, northern Brazil. Total nucleic acids were extracted from two samples of camapu using the protocol of Gibbs and Mackenzie (1997). Subsequently, RT-PCR was performed using the universal primer pair for tospovirus species BR60 (5' AGAGCAATCGTGTCA 3'), designed in the 3' terminal 15 nucleotides of the non-translated region of S RNA, and BR65 (5' ATCAAGCCTTCTGAAAGTCAT 3'), designed in the $\mathrm{N}$ gene, at nucleotide positions 433-453 (Eiras et al. 2001). The $408 \mathrm{bp}$ fragment was sequenced and analyzed using the programs Blast, ClustalW, and Mega 7.0. Results showed the presence of groundnut ringspot virus (GRSV) with nucleotide and amino acid identity of 96-98\%, and 98$100 \%$, respectively, with other GRSV sequences available in GenBank. GRSV isolate Br:Para3 (GenBank accession No. MK501381) grouped with other GRSV isolates in a phylogenetic analysis using Bayesian inference, with a posterior probability of 1 . The symptomatic leaves infected with GRSV were macerated in potassium phosphate buffer solution, $\mathrm{pH} 7.2$, and the extract was transmitted to five plants of each Solanaceae host species cultivated under greenhouse conditions for 20 days to observe the emergence of symptoms. Plants of P. angulata, Datura stramonium, and Nicotiana tabacum 'TNN' reacted with symptoms of systemic necrosis. This is the first report of GRSV infection of camapu. It suggested that camapu can serve as a source of GRSV inoculum for other cultivated plants such as tomato plants.

Acknowledgements This work is supported by Norte Energia SA.

\section{References}

Eiras M, Resende RO, Missiaggia AA, de Avila AC (2001) RT-PCR and dot blot hybridization methods for a universal detection of tospoviruses. Fitopatol Bras 26:170-175

Gibbs A, Mackenzie A (1997) A primer pair for amplifying part of all potyvirids by RT-PCR. J Virol Methods 63:9-16

Publisher's note Springer Nature remains neutral with regard to jurisdictional claims in published maps and institutional affiliations.
Ayane Fernanda Ferreira Quadros

ayane.quadros@ufv.br

Embrapa Amazônia Oriental, Belém, Brazil

2 Universidade Federal Rural da Amazônia, Belém, Brazil

3 Universidade Federal de Viçosa, Viçosa, Brazil 